\title{
$\mathrm{SC}$

\section{OPEN Data Descriptor: High-resolution hydrometeorological data from a network of headwater catchments in the tropical Andes}

Received: 4 December 2017

Accepted: 13 March 2018

Published: 3 July 2018
Boris F. Ochoa-Tocachi et al."

This article presents a hydrometeorological dataset from a network of paired instrumented catchments, obtained by participatory monitoring through a partnership of academic and non-governmental institutions. The network consists of 28 headwater catchments $\left(<20 \mathrm{~km}^{2}\right)$ covering three major biomes in 9 locations of the tropical Andes. The data consist of precipitation event records at $0.254 \mathrm{~mm}$ resolution or finer, water level and streamflow time series at 5 min intervals, data aggregations at hourly and daily scale, a set of hydrological indices derived from the daily time series, and catchment physiographic descriptors. The catchment network is designed to characterise the impacts of land-use and watershed interventions on the catchment hydrological response, with each catchment representing a typical land use and land cover practice within its location. As such, it aims to support evidence-based decision making on land management, in particular evaluating the effectiveness of catchment interventions, for which hydrometeorological data scarcity is a major bottleneck. The data will also be useful for broader research on Andean ecosystems, and their hydrology and meteorology.

\begin{tabular}{|c|c|}
\hline Design Type(s) & observation design time series design data integration objective \\
\hline Measurement Type(s) & physiographic feature $\cdot$ hydrological precipitation process - watercourse \\
\hline Technology Type(s) & observational method data acquisition system \\
\hline Factor Type(s) & temporal_interval • biome \\
\hline Sample Characteristic(s) & $\begin{array}{l}\text { Ecuador Peru Bolivia tundra biome - forest biome }- \text { montane } \\
\text { grassland biome montane shrubland biome }\end{array}$ \\
\hline
\end{tabular}

Correspondence and requests for materials should be addressed to B.O.T. (email: boris.ochoa13@imperial.ac.uk) or to B.D.B. (email: bert.debievre@fonag.org.ec).

${ }^{\#} \mathrm{~A}$ full list of authors and their affiliations appears at the end of the paper. 


\section{Background \& Summary}

Tropical mountain environments host some of the most complex, dynamic, and diverse ecosystems ${ }^{1,2}$, but are under severe threats, ranging from local deforestation and soil degradation ${ }^{3-5}$ to global climate change $^{6-8}$. Despite their importance and vulnerability, there are very few observational data to quantify the impacts of these changes ${ }^{9}$. More extensive observations of climatic conditions at high elevations are urgently needed but monitoring in these areas is expensive and logistically challenging ${ }^{10,11}$. Despite many recent monitoring efforts to fill data gaps in high-altitude environments ${ }^{12}$, many mountain areas still lack a strong evidence base to guide decision-making on catchment interventions, such as re- or afforestation, and different conservation and climate adaptation measures. Driven by global agenda that promotes a better use of ecosystem services and natural capital, such interventions are happening at an accelerating pace, yet their hydrological benefits are insufficiently monitored and often based on anecdotal evidence. This is particularly the case for the tropical Andes, where the complex climatic and hydrological characteristics combined with a very dynamic anthropogenic disturbance put severe pressure on water resources ${ }^{13}$.

This combination of high vulnerability, accelerated change, and data scarcity makes it paramount to explore alternative methods of data collection. Among those, the use of participatory and grassroots approaches of information generation is gaining traction ${ }^{14,15}$. Participatory data collection has the potential to enhance public involvement and to fill long-standing data gaps ${ }^{16-18}$. It also has the potential to complement another major advance in hydrometeorological monitoring, remotely sensed data ${ }^{19-22}$, which are still limited by low spatial and temporal resolutions - usually kilometric areal averages and multi-daily - that impede hydrological assessment of small headwater catchments. Satellite precipitation products, for instance, are available at intra-daily timescales, but they involve large uncertainties and inaccuracies at the point-area difference with respect to surface level rain gauges ${ }^{23,24}$ that difficult their direct assimilation.

As a response to such a monitoring gap, a partnership of academic and non-governmental institutions set up an initiative for participatory hydrological monitoring in the Andes ${ }^{11,25}$. The network known as Regional Initiative for Hydrological Monitoring of Andean Ecosystems (iMHEA) aims to produce information about the impacts of land-use and watershed interventions on hydrological ecosystem services, and to guide processes of decision making on catchment management. Similar bottom-up initiatives have emerged worldwide creating networks of well-monitored experimental sites $^{26}$, for example, the network of terrestrial environmental observatories in Germany (TERENO) ${ }^{27}$. The iMHEA partnership, established in 2009, uses a hydrological design based on a 'trading-space-for-time' approach ${ }^{2-33}$. This concept relies on strengthening the statistical significance of a watershed intervention, such as a land-use signal, by monitoring several paired catchments in a regional setting ${ }^{5}$. The setup of the monitoring sites also allows for robust regionalisation results by covering different ecosystems with diverse physiographic characteristics and contrasting land uses and degrees of conservation/alteration $^{34}$. This paper presents data from 28 catchments from the iMHEA network, representing 16 local stakeholders in 9 sites located in Ecuador, Peru, and Bolivia (Fig. 1). The presented data are composed of precipitation event records at $0.2 \mathrm{~mm}$ resolution, water level and streamflow time series at $5 \mathrm{~min}$ intervals, data aggregated at hourly and daily scale, as well as a set of hydrological indices derived from the daily time series, and catchment physiographic descriptors and geographic information.

The NGO CONDESAN and Imperial College London co-designed and implemented several iMHEA sites with local stakeholders as part of the Mountain-EVO research project (UK NERC grant NEK010239-1) "Adaptive governance of mountain ecosystem services for poverty alleviation enabled by environmental virtual observatories" funded under the Ecosystem Services for Poverty Alleviation programme (www.espa.ac.uk) from 2013 to 2017. The project analysed how monitoring and knowledge generation of ecosystem services in mountain regions can be improved and used to support a process of adaptive, polycentric governance focused on poverty alleviation ${ }^{16,17}$. The data reported here fill longstanding hydrological information gaps allowing for evidence-based, robust predictions and cost-benefit comparisons about the effectiveness of watershed interventions. Such an approach has the potential to alleviate data scarcity in other remote mountain environments and provide relevant input for multi-scale decision making - from community level to national governance entities - ultimately improving the management of water resources and hydrological ecosystem services.

\section{Methods}

\section{Hydrometeorological monitoring design}

A monitoring protocol was designed to optimise the value of the resulting dataset to evaluate the impact of catchment interventions which is available in Ochoa-Tocachi et al. (2017, ref. 25). The protocol is based on a pairwise catchment comparison (Fig. 2) to separate the effects of changes in land use or watershed interventions from those of natural variability in climate and physiography ${ }^{35-37}$.

An idealised paired catchment experiment consists of two catchments that are collocated or in close proximity to each other, and whose physical and climatic characteristics are as similar as possible ${ }^{38}$. These catchments are monitored for a sufficient time to generate a statistical baseline for comparison. Subsequently, one of the catchments is subject to an intervention while the second remains in the original (reference) state. This makes it possible to evaluate the hydrological impact of the intervention, even if boundary conditions -such as climate- change over time. Although the use of a statistical baseline 


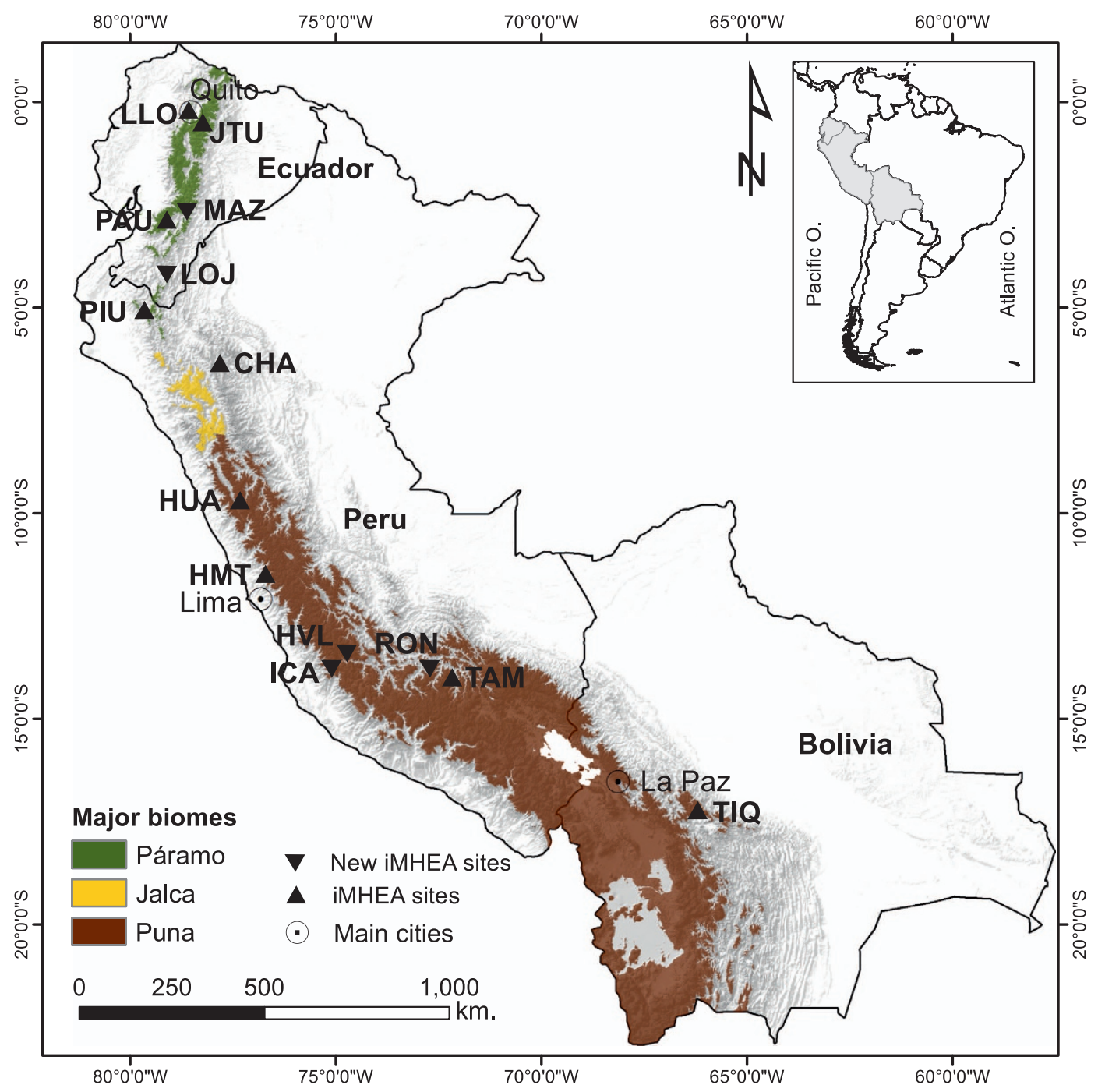

Figure 1. Map of the Regional Initiative for Hydrological Monitoring of Andean Ecosystems (iMHEA). The monitoring sites cover the major high Andean biomes (Páramo, Jalca, and Puna) in 3 countries (Ecuador, Peru, and Bolivia). The complete iMHEA network consists of 16 sites, including one in the Venezuelan Andes. In this article, we present data from the 9 sites identified in the map by up-pointing triangles.

provides the most robust design, this is generally only achievable under strict experimental control of both catchments, which is often not practical. Therefore, a more straightforward 'control-intervention' setup (i.e. without baseline) is more commonly implemented instead, and has proven useful in published case studies ${ }^{5,38,39}$.

A major advantage of the 'control-intervention' setup is that impacts are evaluated by means of a spatial comparison rather than of changes over time, which reduces the length of the monitoring times, but this comes at the expense of a reduced attribution power. Therefore, a careful analysis and interpretation is needed to avoid any incorrect attribution of hydrological differences that may not be caused by the controlled factor but by other variables ${ }^{34,40}$. On the long-term, nonetheless, as the length of the monitoring time series increases ${ }^{26}$, individual catchments can be evaluated for impacts of climatic changes or vegetation physiology, especially in the evaluation of restoration strategies. The long-term sustainability of the monitoring using the paired catchment design can therefore reveal meaningful insights about hydrological non-stationarity. Such sustainability can be achieved by a robust institutional agreement as highlighted below in this article.

In each catchment, we monitored rainfall and streamflow, and measured or calculated several catchment physiographic characteristics (Data Citation 1). In extension, we applied a catchment water balance equation on the dataset of precipitation and discharge to estimate the combined losses, which account for an estimation of total water consumed by vegetation, evaporated from the surface, infiltrated to deeper soil strata, and stored in the soils. On the long-term, the water balance becomes a good approximation of catchment evapotranspiration. However, deep permeable soils and aquifers may be 


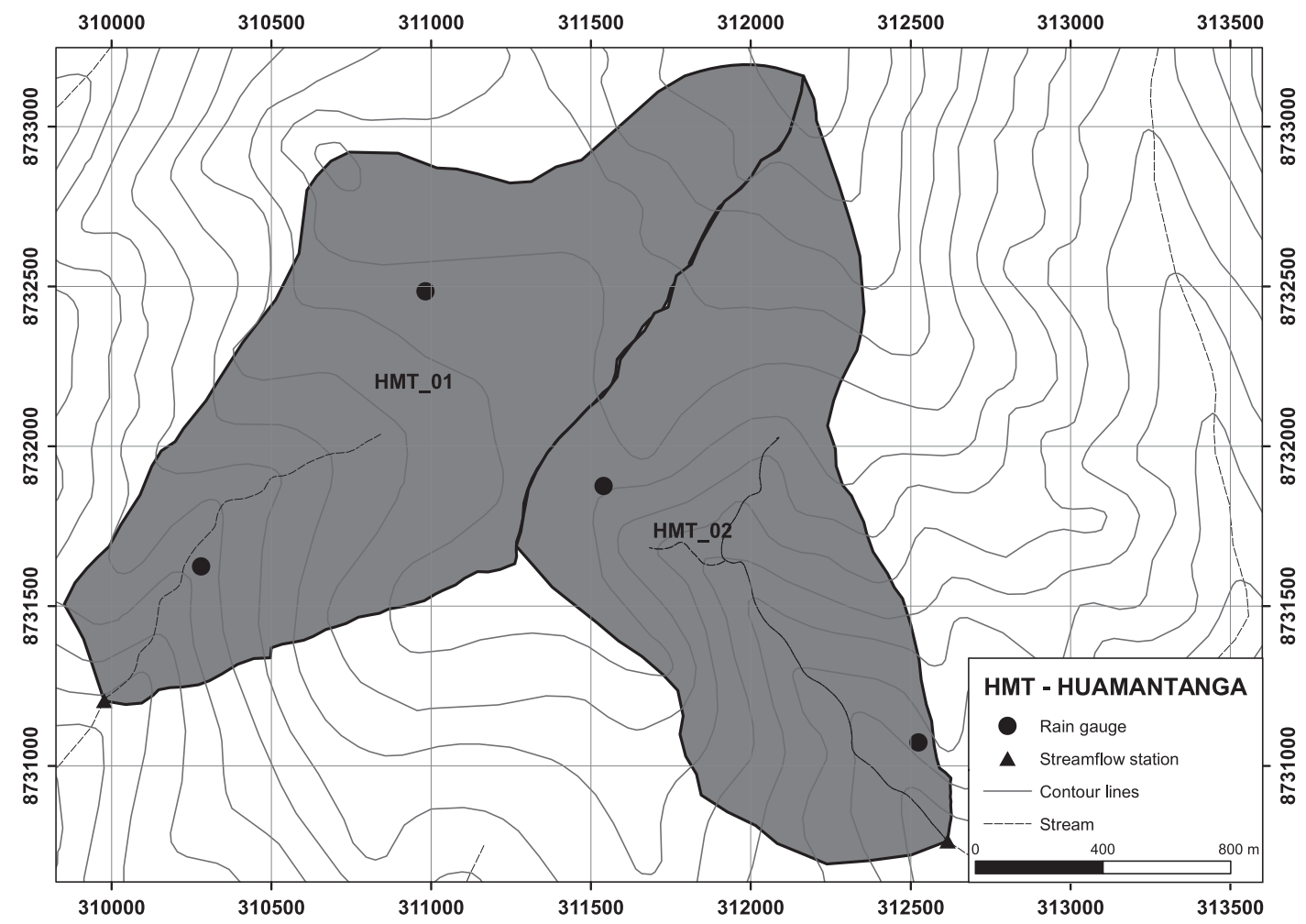

Figure 2. Example of paired catchments monitored at the iMHEA site HMT. Catchments are selected in such a way that they are as physically similar possible. The monitoring system is designed to capture small scale variability in hydrometeorological characteristics. Maps of all catchments are available in the geographic dataset (Data Citation 1). For details of catchment characteristics see Table 1.

present in some regions ${ }^{3,41,42}$ which may challenge the assumption of a closed water balance. In such cases, a careful identification of the catchments has been performed to minimise errors and potential issues in the water balance simplification, or to monitor and consider those elements in the analyses.

\section{Catchment physiography}

Surveys of physical features were performed to select catchments and to document the properties that can influence their hydrological response. These properties were derived from geographic and cartographic data $^{34}$, and divided in categories of shape (area, perimeter, compactness, shape factors, circularity, elongation, equivalent rectangle dimensions), drainage (longest drainage path, longest line parallel to the main stream, drainage density, current frequency, concentration time), elevation (maximum, minimum, mean, range, weighted average, percentiles), topography (hypsometric curve, catchment mean slope, stream mean slope, relief ratio, slope variability, topographic index), subsurface (soil types, soil depths, mean hydraulic conductivity, geology), land cover percentages, and land use types.

A summary of the main catchment characteristics is shown in Table 1. The monitoring sites cover three of the most extensive upper Andean biomes ${ }^{5}$, i.e. páramo, jalca, and puna (Figs $3 \mathrm{a}-\mathrm{c}$ ), with some catchments also covered by high Andean forests. Catchments are small, ranging from $0.5 \mathrm{~km}^{2}$ to $20 \mathrm{~km}^{2}$, and located between $2000 \mathrm{~m}$ and $5000 \mathrm{~m}$ altitude. They feature a typical mountainous topography, with steep and uneven slopes, and oval shapes tending to circular or stretched. Sites are rural and the main land use types are conservation, grazing, afforestation, and cultivation (Figs $3 \mathrm{~d}-\mathrm{f}$ ). Vegetation cover is generally natural and mostly consists of tussock and short grasses, shrubs patches with eventual occurrences of native and exotic forest, and small wetlands in the flat valley bottoms. Catchments classified as forested have at least $80 \%$ of their area under forest cover. No water abstractions or alterations are present upstream of the streamflow monitoring stations.

\section{Precipitation}

Rainfall is the main component of precipitation in Andean catchments ${ }^{43}$. Precipitation was measured using electronic tipping bucket rain gauges (Onset HOBO Data Logging Rain Gauge, Davis Instruments Rain Collector II, or Texas Electronics Collector Rain Gauge), installed at a height above the ground of $1.50 \mathrm{~m}$. Their resolution is of at least $0.254 \mathrm{~mm}(0.1 \mathrm{in})$, but typically $0.2 \mathrm{~mm}$, and exceptionally $0.1 \mathrm{~mm}$. At least two rain gauges were located to improve capturing the catchment area and its elevation range, which is known to generate high spatial variability ${ }^{44,45}$. Furthermore, locations were selected for regional 


\begin{tabular}{|c|c|c|c|c|c|c|c|c|}
\hline Code & Biome & Altitude $\mathbf{m}$ a.s.l. & Area $\mathrm{km}^{2}$ & Shape & Slope & Soils & Land use & Land cover \% approx. \\
\hline LLO_01 & Páramo & $3825-4700$ & 1.79 & Stretched oval & Strongly uneven & Andosol & Grazing, burning & Tussock grass (90), shrubs (10) \\
\hline LLO_02 & Páramo & $4088-4680$ & 2.21 & Stretched oval & Uneven & Andosol, Histosol & Grazing, restoration & Tussock grass (70), native forest (10), wetlands (20) \\
\hline JTU_01 & Páramo & $4075-4225$ & 0.65 & Oval & Uneven & Andosol & Grazing & Tussock grass (100) \\
\hline JTU_02 & Páramo & $4085-4322$ & 2.42 & Oval & Uneven & Andosol & Grazing & Tussock grass (100) \\
\hline JTU_03 & Páramo & $4144-4500$ & 2.25 & Circular oval & Uneven & Andosol, Histosol & Natural & Tussock grass (80), shrubs (20) \\
\hline JTU_0 $04^{\mathrm{a}}$ & Páramo & $3990-4530$ & 16.05 & Stretched oval & Uneven & Andosol, Histosol & Grazing, natural, restoration & Tussock grass (70), shrubs (10), wetlands (5), nude soil (15) \\
\hline PAU_01 & Páramo & $3665-4100$ & 2.63 & Circular oval & Uneven & Andosol & Natural & Tussock grass (100) \\
\hline PAU_02 & Páramo & $2970-3810$ & 1.00 & Oval & Strongly uneven & Andosol, Histosol & Natural, grazing & Tussock grass (80), native forest (20) \\
\hline PAU_03 & Páramo & $3245-3680$ & 0.59 & Circular oval & Strongly uneven & Andosol, Histosol & Afforestation & Tussock grass (10), pine plantation (90) \\
\hline PAU_04 & Páramo & $3560-3721$ & 1.55 & Circular oval & Uneven & Andosol & Cultivation, grazing & Tussock grass (70), crops (30) \\
\hline PAU_05 ${ }^{\mathrm{b}}$ & Páramo & $3300-3500$ & - & - & - & Andosol, Cambisol & Natural & Tussock grass, shrubs \\
\hline PIU_01 & Páramo & $3112-3900$ & 6.60 & Circular oval & Uneven & Andosol, Histosol & Natural & Tussock grass (75), native forest (15), lagoon (10) \\
\hline PIU_02 & Páramo & $3245-3610$ & 0.95 & Circular oval & Strongly uneven & Andosol, Histosol & Grazing & Tussock grass (75), nude rock (15), lagoon (10) \\
\hline PIU_03 & Páramo & $3425-3860$ & 1.31 & Circular oval & Strongly uneven & Andosol, Histosol & Grazing & Tussock grass (90), lagoon (10) \\
\hline PIU_04 & Forest & $2682-3408$ & 2.32 & Oval & Strongly uneven & Andosol, Cambisol & Natural forest & Grass (20), native forest $(80)$ \\
\hline PIU_05 ${ }^{\mathrm{b}}$ & Forest & $1972-2176$ & - & - & - & Andosol, Cambisol & Cultivation, forest & Native forest, crops \\
\hline PIU_06 ${ }^{\mathrm{b}}$ & Forest & $2782-3078$ & - & - & - & Andosol, Cambisol & Cultivation, forest & Native forest, crops \\
\hline PIU_07 & Dry puna & $3110-3660$ & 7.80 & Oval & Uneven & Andosol & Grazing, cultivation & Tussock grass (45), shrubs (20), crops (35) \\
\hline CHA_01 & Jalca & $2940-3200$ & 0.95 & Oval & Uneven & Andosol, Inceptisol & Afforestation & Tussock grass (20), pine plantation (80) \\
\hline CHA_02 & Jalca & $3000-3450$ & 1.63 & Oval & Uneven & Andosol, Inceptisol & Natural & Tussock grass (90), native forest (10) \\
\hline HUA_01 & Humid puna & $4280-4840$ & 4.22 & $\mathrm{CO}$ & Uneven & Andosol, Histosol & Natural & Tussock grass (60), nude rock (25), wetlands (15) \\
\hline HUA_02 ${ }^{c}$ & Humid puna & $4235-4725$ & 2.38 & Oval & Uneven & Andosol, Histosol & Grazing & Tussock grass (55), nude rock (30), wetlands (15) \\
\hline HMT_01 & Dry puna & $4025-4542$ & 2.09 & Oval & Uneven & Leptosol, Inceptisol & Grazing & Grass (75), nude soil (15), shrubs (10) \\
\hline HMT_02 & Dry puna & 3988-4532 & 1.69 & Oval & Strongly uneven & Leptosol, Inceptisol & Grazing & Grass (85), nude soil (10), shrubs (5) \\
\hline TAM_01 & Humid puna & $3835-4026$ & 0.82 & Oval & Uneven & Leptosol, Inceptisol & Afforestation, grazing & Grass (80), pine plantation (20) \\
\hline TAM_02 & Humid puna & $3650-4360$ & 1.67 & Circular oval & Strongly uneven & Leptosol, Inceptisol & Natural, forest & Grass (60), native forest (40) \\
\hline TIQ_01 & Humid puna & $4140-4353$ & 0.69 & Oval & Uneven & Leptosol, Inceptisol & Cultivation, grazing & Grass and crops $(70)$, nude soil $(30)$ \\
\hline TIQ_02 & Humid puna & $4182-4489$ & 1.73 & Stretched oval & Uneven & Leptosol, Inceptisol & Natural & Tussock grass (90), nude soil (5), lagoon (5) \\
\hline
\end{tabular}

Table 1. Description of the monitored catchments. For a reference of site codes, see Table 2. ${ }^{\mathrm{a} T T U} \mathrm{~T} 04$

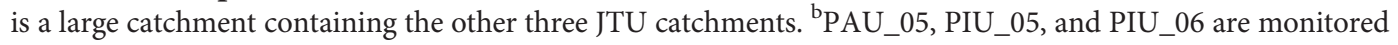
for rainfall only and, as they lack streamflow data, their areas are not defined. ${ }^{\circ}$ The discharge station in HUA_02 was initially located downstream from its current position defining an area of $2.71 \mathrm{~km}^{2}$; data from this early period have been normalised during the data processing to use only the current area shown here.

representativeness and to minimise measurement errors such as those caused by wind effects ${ }^{46-48}$. Correlation analysis and double mass plots between the rain gauges were used to detect and correct errors and to fill data gaps. Automatic precipitation records were validated using manual rain gauges. In areas with potential snowfall occurrence, the equipment is above the maximum expected snow height accumulation in the ground, and an antifreeze substance has been recommended to melt ice and snow ${ }^{25}$. However, snowfall is rare within the monitored elevation range in the tropical Andes and has not been reported by local monitoring operators.

Tip time stamps were transformed to rainfall volumes depending on the rain gauge resolution. A composite cubic spline interpolation ${ }^{49,50}$ was applied to the cumulative rainfall curve to generate rainfall intensities at $1 \mathrm{~min}$ resolution. This procedure generates better results than simple tip counting or linear interpolation $^{51}$ (Fig. 4). Rainfall data were then aggregated at time intervals matching those of the corresponding discharge in the catchment, and also at $1 \mathrm{hr}$ and 1 day resolutions. From these data, we derived summarising indices including average annual precipitation, wetness index, days with zero rainfall, precipitation of the driest month, coefficient of variation in daily precipitation, and seasonality index ${ }^{52}$. For the calculation of median and maximum rainfall intensities, we used a 5 min scale moving window for storm durations between $5 \mathrm{~min}$ and 2 days. As most of the catchments lack a full meteorological station, the wetness index (ratio between annual precipitation and evapotranspiration) was calculated using WorldClim temperature data ${ }^{53}$ and the Hargreaves formula ${ }^{54,55}$.

\section{Streamflow}

Discharge was obtained by measuring water level using automatic pressure transducers (Onset HOBO U20 Water Level Loggers, Schlumberger Water Services Diver and Baro-Diver, Solinst Levelogger 3001, 

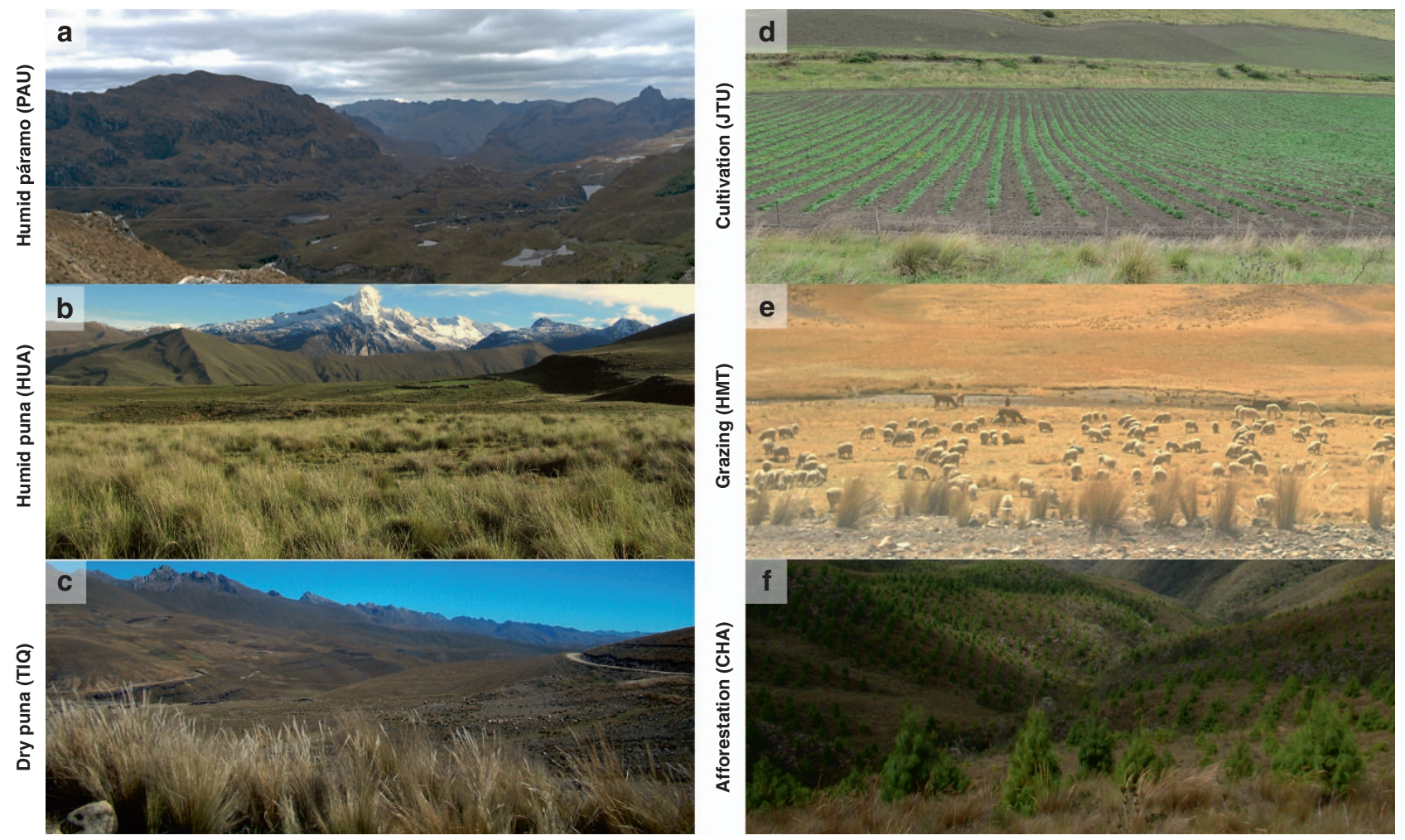

Figure 3. Representative landscapes of the monitored catchments. The iMHEA network covers major high Andean biomes, including (a) Humid páramo in southern Ecuador (e.g., PAU), (b) Humid puna in central Peru (e.g., HUA), and (c) Dry puna in central Bolivia (e.g., TIQ). Land use types include common human activities such as (d) cultivation of potato and tubers (e.g., JTU), (e) livestock grazing (e.g., HMT), and (f) afforestation with exotic tree species (e.g., CHA). For a reference of site codes and locations, see Fig. 1 and Table 1.

Global Water WL16, or Instrumentation Northwest AquiStar PT2X Smart Sensor). Water level was recorded at a regular interval of at least $15 \mathrm{~min}$ and generally $5 \mathrm{~min}$, although some catchment data are limited to $30 \mathrm{~min}$ intervals. The measurement resolution ranges between 0.1 to $0.5 \mathrm{~mm}$. The high temporal resolution of the recordings allows capturing the rapid hydrological response of small catchments after precipitation events, which can reach peak flows in only a few minutes (Fig. 4).

Compound sharp-crested weirs were used to rely on an established stage-discharge relation ${ }^{47}$. A compound weir combines a $\mathrm{V}$-shaped section for accurate monitoring of minimum flows, and a triangular-rectangular section to contain peak flows. Manual flow velocity measurements were used to cross-check automatic water level records. The Kindsvater-Shen relation ${ }^{56}$ was used to transform water level to discharge, and then revised with flow observations. Discharge data were normalised by catchment area (units of $\mathrm{mm}$ or $1 \mathrm{~s}^{-1} \mathrm{~km}^{-2}$ ) to enable comparison between catchments and water balance calculations with rainfall. These data were kept at the maximum temporal resolution and averaged at $1 \mathrm{hr}$ and 1 day resolutions, from which a set of hydrological indices was computed.

\section{Derived hydrological indices}

The hydrological literature offers a large number of indices (also known as streamflow signatures) that characterise different features of the hydrological regime ${ }^{57-59}$. Indices are useful to represent several conservation/alteration conditions in catchments by means of streamflow information. Streamflow data are typically analysed in terms of five major response characteristics: (i) Magnitude (flow at any given time interval and location); (ii) Frequency (how often a flow above a threshold recurs over time); (iii) Duration (period of time over which a specific flow condition exists); (iv) Timing/Predictability (regularity with which a flow of a predefined magnitude occurs); and, (v) Rate of change/Flashiness (how quickly the flow magnitude changes). These characteristics can be subdivided further in low, average, and high flows.

We selected hydrological indices that are independent ${ }^{37,60}$, unambiguous ${ }^{59,61}$, and respond to the contextualised practical issue ${ }^{34,62}$, i.e., those that show evidence of change under watershed interventions, land use changes, or green infrastructure implementation. iMHEA partners are particularly interested in characterising water yield (flow statistics such as minimum, maximum, median, annual mean, long-term mean, driest month flow, and flow percentiles), hydrological regulation (baseflow index, recession constant, discharge range, slope of the flow duration curve, hydrological regulation index, Richards-Baker 

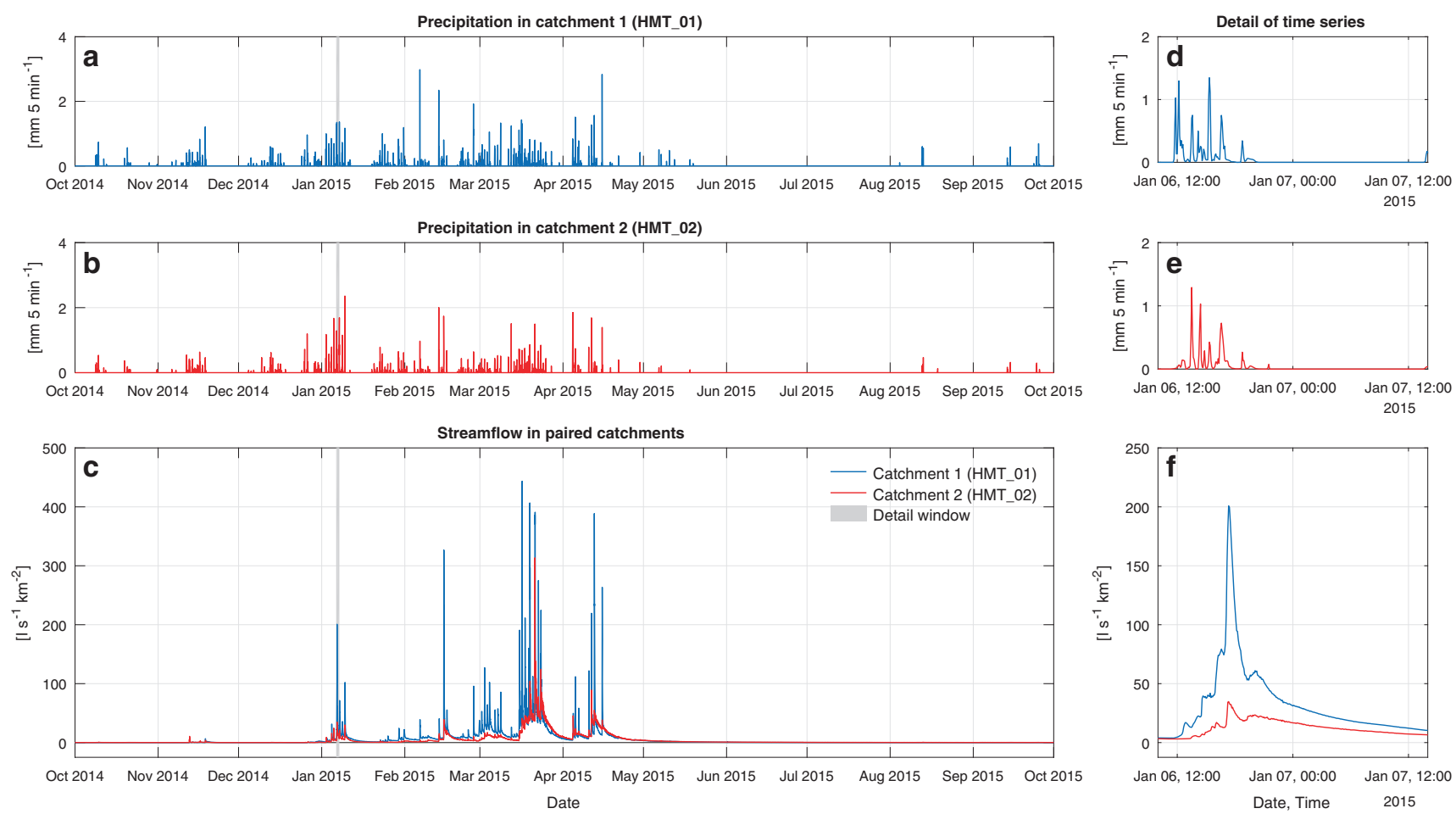

Figure 4. Representative sample of the generated time series. Precipitation (a,b) and streamflow (c) data from the paired catchments at the iMHEA site HMT (see Fig. 2). The variables are monitored at high resolution, which allows for a very detailed characterisation of hydrometeorological regimes (d-f).

flashiness index ${ }^{63}$ ), and water balance (dry month discharge ratio, dry month discharge range, average annual discharge, runoff ratio). This list has been further expanded to include selected indices ${ }^{34,59}$ of magnitude (skewness in daily flows, coefficients of variation, discharge ranges), high and low flow pulse analysis (magnitude, volume, frequency, and duration), timing (flood occurrence or absence, Julian day of extremes), and flashiness (flow reversals, logarithm of increasing and decreasing flow differences, ratio of days with increasing flow). We developed scripts to derive the several hydrological indices from normalised daily discharge data ${ }^{34}$.

One particular interest in the monitoring of small and seasonal catchments is the characterisation of low flow conditions. The Base Flow Index (BFI), calculated as the ratio between baseflow to total flow, is interpreted as the proportion of river discharge that originates from internal catchment stores ${ }^{64}$. We followed two different procedures to derive baseflow time series and the BFI. The first method follows the UK Flood Estimation Handbook ${ }^{64}$ dividing the mean daily flow data into non-overlapping blocks of five days. The method calculates the minima of these consecutive periods and subsequently searches for turning points in this sequence. Daily values of baseflow are calculated by linear interpolation between these turning points and constrained by the original hydrograph when the separated hydrograph exceeds the observed. Baseflow time series are included in the daily flow dataset (Data Citation 1). The second method follows the Boughton two-parameter algorithm ${ }^{65}$ with a filter parameter of 0.85 that is fitted subjectively. The twoparameter algorithm provides more consistent results than either a one-parameter algorithm based on the recession constant or than the IHACRES three-parameter algorithm ${ }^{65}$. We identified baseflow recessions as sections of the hydrograph of at least a 7 day duration that were apparently linear $\left(\mathrm{R}^{2}>0.8\right)$ on a logarithmic scale for flows, from which the hydrograph recession constant was calculated. The presented hydrological indices include BFI and recession constants obtained by the two methods.

\section{Institutional agreement for participatory monitoring}

The monitoring sites implemented by the iMHEA network aim to achieve optimal complementarity with existing monitoring networks in the $\mathrm{Andes}^{11}$ and with national authorities of water, environment, hydrology and meteorology ${ }^{25}$. iMHEA's grassroots approach is based on the assumption that civil society-based institutions can contribute with local scale and headwater monitoring to cover remote areas, thus complementing other efforts of data collection. The high spatiotemporal resolution of these data is compatible with the generally long-term and low-spatial density of national networks ${ }^{17,47}$.

The monitoring system includes an institutional agreement between local users of land and water, development organisations or local government offices, academic institutions, and other monitoring networks. Local communities and institutions are responsible for sensor installation, operation, 
maintenance, and security and logistical tasks. Quality control and scientific rigour are achieved by research groups and universities who process and interpret the data. Such interaction, often understood as a form of citizen science ${ }^{16-18}$, has shown strong potential to tackle data scarcity in remote regions such as the tropical Andes. Observational data from experimental catchments have an essential value for hydrology and water resources management that increases with time ${ }^{26}$. As one of iMHEA's fundamental principle, this value is leveraged when information is shared at multiple levels for diverse audiences with the aim to inform decision-making processes more effectively. The network is interested in improving the management of water resources and hydrological ecosystem services in the Andean region, especially, to support the evaluation of the hydrological- and cost-effectiveness of watershed interventions. This institutional agreement provides an exemplary model to ensure the sustainability of monitoring networks in other contexts as well.

\section{Code availability}

The codes used to process the iMHEA data are in the form of freely available MATLAB scripts (Data Citation 1). Calculations were done using MATLAB R2017a (version 9.2) under an Academic License provided by Imperial College London. Revised or improved versions of the code and adapted scripts for R and Python are also available in a GitHub repository ${ }^{66}$.

\section{Data Records}

The list of the observatories used to generate the information in the present dataset is shown in Table 2. In this data descriptor, we present data from 9 sites of the iMHEA network, which account for 28 catchments comprising 67 rain gauges and 25 streamflow stations. Each site has a particular research question being addressed by the monitoring which generally fits under three broad categories: hydrological impacts of human activities, hydrological benefits of watershed interventions, and characterisation of hydrological processes. A summary of the dataset and monitored variables is provided in Table 3.

The data are intended to support decision making at multiple levels, both addressing relevant local questions and supporting regional analyses of water resources in the Andes. The hydrometeorological data as presented in this paper are archived at the public repository Figshare (Data Citation 1). A backup of the data, including the original raw files obtained from each particular monitoring sensor and expansions with further data updates, can be requested to the iMHEA network via the corresponding authors.

The file format is CSV. The naming convention for the sensor data is:

$i M H E A_{-}<$site code $\rangle_{-}<$catchment number $\rangle_{-}<$variable $\rangle_{-}<$sensor number $\rangle_{\text {_raw.csv }}$

The naming convention for the compiled, processed catchment data is:

$i M H E A_{-}<$site code $>_{-}<$catchment number $\rangle_{-}<$temporal resolution $\rangle_{\text {_p processed.cs } v}$

The naming convention for the catchment properties and indices is:

iMHEA_Indices_<index type >.csv

The naming convention for the geographic data is:

$i M H E A_{-}<$site code $>_{-}<$catchment number $>_{-}<$geodata type $>$

The site codes are defined by the three letters shown in Table 2 . The variables are identified by two letters, where the first indicates the type of station ('P' for pluviometric, ' $\mathrm{H}$ ' for hydrological). The second the type of sensor, ('O' for Onset HOBO, 'D' for Davis Instruments, ' $T$ ' for Texas Electronics) for precipitation, and ('O' for Onset HOBO, 'S' for Solinst, 'D' Schlumberger Diver, 'W' for Global Water, and 'I' for Instrumentation Northwest) for discharge measurement. Numbers identify catchments and sensor locations and are used to organise the matrices of physical and climatic characteristics and hydrological indices (Table 3). Geographic data include catchment delineation, sensor location, contour lines, drainage network, lithology, land cover, and digital elevation model.

\section{Technical Validation}

\section{Regional representativeness and monitoring coverage}

To maximise the regional representativeness of the tropical Andes and the potential for impact attribution, catchments were chosen to be hydrologically representative of a single land cover in the surrounding area $^{34}$ (Fig. 3). Large catchments usually host various ecosystems or land uses, and therefore observational records may not capture the hydrological signals of individual management practices or land cover. This would make it difficult to attribute a streamflow response to the effect of a specific catchment intervention. As a result, the monitored catchments here are smaller than $20 \mathrm{~km}^{2}$ and host a homogeneous land use in at least $75 \%$ of their areas ${ }^{25}$. However, very small catchments $\left(<0.2 \mathrm{~km}^{2}\right)$ may have some experimental issues as well. For instance, in those with extensive wetland areas, subsurface water flow can become important ${ }^{42}$, increasing the risk of subsurface flow bypassing the flow gauging station. For this reason, our design avoids zero-order catchments ${ }^{25}$.

The number of stations necessary to approximate catchment rainfall input depends on the catchment area and the expected spatial rainfall variability therein ${ }^{44}$. A sub- or an over-estimation of total rainfall at 


\begin{tabular}{|c|c|c|c|c|}
\hline Site code, name, country & Biome types & Monitoring design & Monitoring period & Research questions / partners \\
\hline LLO, Lloa, Ecuador & Páramo & $2 \mathrm{C} / 4 \mathrm{P} / 2 \mathrm{H}$ & 01/2013-01/2017 & $\begin{array}{l}\text { Impacts of grazing, burning, and deep soil hydrological connectivity / Fondo para la Protección del Agua } \\
\text { (FONAG); Junta Parroquial de Lloa (local government) }\end{array}$ \\
\hline JTU, Jatunhuayco, Ecuador & Páramo & $4 \mathrm{C} / 8 \mathrm{P} / 4 \mathrm{H}$ & $11 / 2013-01 / 2017$ & Hydrological benefits of restoration strategies / FONAG; Escuela Politécnica Nacional de Quito \\
\hline PAU, Paute, Ecuador & Páramo & $5 \mathrm{C} / 13 \mathrm{P} / 4 \mathrm{H}$ & 05/2001-07/2007 & $\begin{array}{l}\text { Hydrological impacts of afforestation and cultivation in humid páramo / Universidad de Cuenca; Empresa } \\
\text { pública municipal de telecomunicaciones, agua potable, alcantarillado y saneamiento de Cuenca (ETAPA EP) }\end{array}$ \\
\hline PIU, Piura, Peru & Páramo; Forest & $7 \mathrm{C} / 20 \mathrm{P} / 5 \mathrm{H}$ & 04/2013-01/2017 & $\begin{array}{l}\text { Benefits of conservation and impacts of land use for downstream users / Nature and Culture International } \\
\text { (NCI) }\end{array}$ \\
\hline CHA, Chachapoyas, Peru & Jalca & $2 \mathrm{C} / 2 \mathrm{P} / 2 \mathrm{H}$ & $09 / 2010-12 / 2015$ & $\begin{array}{l}\text { Impacts of pine afforestation / Asociación Peruana para la Conservación de la Naturaleza (APECO); } \\
\text { Universidad Nacional de Colombia. }\end{array}$ \\
\hline HUA, Huaraz, Peru & Humid puna & $2 \mathrm{C} / 6 \mathrm{P} / 4 \mathrm{H}$ & $02 / 2011-09 / 2014$ & $\begin{array}{l}\text { Hydrological benefits of pasture restoration and impacts of grazing / The Mountain Institute; Universidad } \\
\text { Nacional Santiago Antúnez de Mayolo }\end{array}$ \\
\hline HMT, Huamantanga, Peru & Dry puna & $2 \mathrm{C} / 4 \mathrm{P} / 2 \mathrm{H}$ & $06 / 2014-01 / 2017$ & $\begin{array}{l}\text { Hydrological benefits of pasture restoration, impacts of grazing, and hydrological characterisation of water } \\
\text { harvesting techniques / CONDESAN; Universidad Nacional Agraria La Molina; Imperial College London }\end{array}$ \\
\hline TAM, Tambobamba, Peru & Humid puna & $2 \mathrm{C} / 6 \mathrm{P} / 2 \mathrm{H}$ & $04 / 2012-04 / 2013$ & Impacts of pine afforestation and infiltration trenches / Municipalidad Provincial de Cotabambas \\
\hline TIQ, Tiquipaya, Bolivia & Humid puna & $2 \mathrm{C} / 4 \mathrm{P} / 2 \mathrm{H}$ & $02 / 2013-01 / 2016$ & Impacts of cultivation and grazing / Laboratorio de Hidráulica - Universidad Mayor de San Simón \\
\hline
\end{tabular}

Table 2. Summary of the iMHEA monitoring sites presented in the dataset (Data Citation 1). Letters ' $\mathrm{C}$ ', ' $\mathrm{P}$ ', and ' $\mathrm{H}$ ' in column 3 indicate the number of catchments, rain gauges, and streamflow stations for each site, respectively. Site locations are shown in Fig. 1.

a catchment level can lead to erroneous water balances and wrong conclusions about the impacts of different watershed interventions ${ }^{25}$. This is not a problem of the data themselves, but of their spatial extrapolation. Additionally, it has been found that tipping bucket rain gauges may underestimate total precipitation by around $15 \%$ for low intensity events in high Andean catchments ${ }^{43}$. Therefore, most of the iMHEA monitoring sites are equipped with 3 rain gauges at representative low, middle and high elevation points within the catchments ${ }^{5}$, or at least 2 rain gauges in the smaller areas (Table 4 (available online only)). This also allows validation and correction of measurements if one of the sensors fails, for example, due to battery or memory issues or inlet obstructions.

\section{Data collection and storage}

As small mountain catchments feature a rapid hydrological response to precipitation events, the frequency of discharge data monitoring in the iMHEA sites is high (Table 4 (available online only)). The recommended minimum temporal interval for measuring water level is $15 \mathrm{~min}$, but most of the stations record water levels every 5 minutes ${ }^{25}$. Tipping bucket rain gauges typically record data as tip time stamps (events), but a few stations use dataloggers that aggregate data at fixed intervals (Table 4 (available online only)). The exception is site CHA where rainfall and streamflow are both monitored at an interval of $30 \mathrm{~min}$. The high temporal resolution allows identifying impacts on the short-term hydrological regulation, such as streamflow flashiness or hydrograph recession behaviour, that can be overlooked in aggregated indices ${ }^{5}$.

Although the most advanced sensors may have the capacity to store large amounts of data, batteries and data loggers have commonly a limited capacity to function for longer periods in harsh climatic conditions. These conditions and the remote locations reduce the possibility for regular sensor maintenance ${ }^{25}$. As a result, issues such as obstructions in the rain gauge orifices by forest litter or small animals may have occasionally occurred. To avoid the loss of important information, data are retrieved from each sensor approximately once a month.

Quality control of the generated data was performed immediately after the data have been collected in order to identify errors such as data outside the expected measurement range, negative water level values, or potential outliers such as extreme rainfall intensities. Data are curated thoroughly before their posterior processing and analysis as explained below. The high-resolution time series aggregated at different time intervals $(5,15,60 \mathrm{~min}$, or 1 day) represent a large amount of information in the long term (Figs $4 \mathrm{a}-\mathrm{c}$ ). However, it is imperative for impact assessment to store the finest resolution data to avoid losing important information that could be used in diverse studies and analyses ${ }^{5,34}$.

\section{Precipitation data uncertainty, quality control, and processing}

We identify four main uncertainty sources in the monitoring and processing of rainfall data (Table 5): (i) equipment malfunction uncertainty, (ii) measurement errors, (iii) rainfall intensity interpolation, and (iv) spatial interpolation.

Equipment malfunction uncertainty can be investigated by comparing data with and without quality control $^{67}$. Our rainfall data are first curated by differentiating between rainfall tip time stamps and software communication and functioning logs. The latter time stamps are still kept in the raw data files but flagged as 'I' when the sensor is launched, 'D' when data have been downloaded from the sensor, and ' $\mathrm{X}$ ' when software logs have been removed from the rainfall count. Potentially erroneous tips (e.g, as a result of manipulating the rain gauge) have been flagged with an ' $\mathrm{X}$ '. Other anomalies in the data, such as unrealistically high rainfall intensities, have been flagged in the raw files with the letter ' $P$ '. 


\begin{tabular}{|c|c|c|c|c|}
\hline $\begin{array}{l}\text { Variable } \\
\text { Name }\end{array}$ & Raw data & Methods & Processed data & Details \\
\hline Precipitation & $\begin{array}{l}\text { One file per sensor, geoposition } \\
\text { Rain gauge tips at } 0.254,0.2 \text {, or } 0.1 \mathrm{~mm} \text {; or cumulative } \\
\text { values at } 5 \text { or } 30 \mathrm{~min} \text { resolution }\end{array}$ & $\begin{array}{l}\text { Tip depuration, } \\
\text { Cubic spline interpolation on the } \\
\text { cumulative rainfall curve, } \\
\text { Rainfall accumulation, } \\
\text { Data gap filling }\end{array}$ & $\begin{array}{l}\text { One file per catchment, } \\
\text { Precipitation time series at maximum } \\
\text { temporal resolution matching discharge, } \\
\text { and at } 1 \mathrm{hr} \text { and } 1 \text { day resolutions }\end{array}$ & $\begin{array}{l}\text { Units: rainfall (mm). } \\
\text { Some stations (JTU, CHA) lack rain } \\
\text { gauge tip data as the logger was } \\
\text { programmed to store } \\
\text { cumulative values only }\end{array}$ \\
\hline Streamflow & $\begin{array}{l}\text { One file per sensor, geoposition, } \\
\text { Water level instantaneous measurements at } 5,15 \text {, or } \\
30 \text { min resolution }\end{array}$ & $\begin{array}{l}\text { Water level validation, } \\
\text { Discharge calculation, } \\
\text { Restricted data gap filling }\end{array}$ & $\begin{array}{l}\text { One file per catchment, } \\
\text { Streamflow time series at maximum } \\
\text { temporal resolution, and at } 1 \mathrm{hr} \text { and } \\
1 \text { day resolutions }\end{array}$ & $\begin{array}{l}\text { Units: water level }(\mathrm{cm}) \\
\text { streamflow }\left(1 \mathrm{~s}^{-1} \mathrm{~km}^{-2}\right) \\
\text { Weir dimensions used to } \\
\text { convert water level to discharge } \\
\text { for each station in Table } 6\end{array}$ \\
\hline $\begin{array}{l}\text { Catchment } \\
\text { characteristics }\end{array}$ & Geographic information data & $\begin{array}{l}\text { Calculations using Geographic Information } \\
\text { Systems software and custom scripts }\end{array}$ & $\begin{array}{l}\text { Matrix of physical characteristics (rows) } \\
\text { for each catchment (columns) } \\
\text { Maps of each catchment or pair of } \\
\text { catchments }\end{array}$ & $\begin{array}{l}\text { Categories: shape, drainage, } \\
\text { elevation, topography, subsurface, } \\
\text { climate, rainfall intensity, land } \\
\text { cover and land use }\end{array}$ \\
\hline $\begin{array}{l}\text { Hydrological } \\
\text { indices }\end{array}$ & & $\begin{array}{l}\text { Hydrological index calculation based on } \\
\text { custom scripts, averaged over their } \\
\text { monitoring periods }\end{array}$ & $\begin{array}{l}\text { Matrix of hydrological indices (rows) } \\
\text { for each catchment (columns) }\end{array}$ & $\begin{array}{l}\text { Categories: water yield, hydrological } \\
\text { regulation, water balance, magnitude, } \\
\text { frequency, duration, timing, flashiness }\end{array}$ \\
\hline
\end{tabular}

Table 3. Overview of the variables included in the dataset (Data Citation 1).

Measurement uncertainty includes random errors such as turbulent airflow around the gauge ${ }^{48,51}$. Systematic errors, for example, underestimation of real rainfall due to wind loss, wetting loss, and splashin/out, could theoretically be corrected when site-specific information is available ${ }^{68}$. We have found that the Onset HOBO rain gauges are prone to systematic anomaly, in which some time stamp intervals are exactly $1 \mathrm{~s}$ from the previous, which is the maximum time resolution of the data logger. Two tips of 0.2 $\mathrm{mm}$ with an interval of $1 \mathrm{~s}$ would represent a rainfall intensity of $720 \mathrm{~mm} \mathrm{hr}^{-1}$. According to its manual ${ }^{69}$ , the maximum rainfall intensity that this rain gauge can measure is $127 \mathrm{~mm} \mathrm{hr}^{-1}$, and thus these immediate consecutive events where removed during the data depuration and processing. The standard deviation of the relative error in $1 \mathrm{hr}$ rainfall rates can be approximated as a function of rainfall intensity $^{51}$, which can then be used to estimate point measurement errors assuming a Gaussian distribution with zero mean ${ }^{67}$. By doing this, measurement uncertainty has been found to have only a small effect on the error standard deviation ${ }^{67}$.

Tipping bucket rain gauges aggregate rainfall data in the time domain, which complicates the estimation of rainfall intensities ${ }^{68}$. We use a composite cubic spline interpolation to generate a piecewise continuous curve that is thought to be the most accurate representation of rainfall rates ${ }^{50,70}$ (Figs $4 \mathrm{~d}$ and e), but this is based on several assumptions ${ }^{43,49-51}$. Four threshold intensities were defined: (i) a minimum intensity to separate rainfall events, which depends on the rainfall structure of the studied region (here, $\left.0.2 \mathrm{~mm} \mathrm{hr}^{-1}\right)^{43}$; (ii) a maximum intensity to merge consecutive tips, which is mainly to avoid issues when concatenating consecutive high- and low-intensity intervals (here, $127 \mathrm{~mm} \mathrm{hr}^{-1}$ ) (iii) a mean intensity to distribute single tips due to the lack of information to interpolate them (here, $\left.3 \mathrm{~mm} \mathrm{hr}^{-1}\right)^{50}$; and, (iv) a low threshold intensity above which data are accepted to avoid having

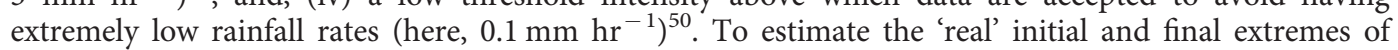
rainfall events, we assumed that they occur at half the rainfall rate of the two extreme rainfall tips and considered half partial tip remaining in the bucket from the previous event ${ }^{49}$. The first derivatives are then set to zero at these new defined extremes when applying the cubic spline interpolation. This improves the rainfall rate interpolation at the extremes of rainfall events and is otherwise equivalent to not estimating the initial and end points and setting the second derivatives to zero at the extremes.

Data were aggregated at $1 \mathrm{~min}$ resolution using tip counting before proceeding with the interpolation ${ }^{50}$. In the case that independent rainfall events had only 2 data points, a linear interpolation ${ }^{51}$ was used instead. Mass-conservation and discontinuities were checked in the interpolated data for each independent rainfall event $t^{50}$ : (i) when the estimated rainfall rates were negative (produced by a rapid change in the spline slopes between high and low rainfall rates), they were replaced by zero; (ii) rates that were between 0 and the low threshold intensity are replaced by this low threshold intensity; (iii) the resulting bias between the original and the interpolated rainfall totals was corrected by re-scaling the remaining intensities. Then, the cumulative rainfall curve was reconstructed by consecutively adding the corrected rainfall rates. In the rare cases when the bias after the interpolation was unacceptably large (here, $>25 \%$, although some studies use a tolerance of as much as 50\% (ref. 50)), the cubic spline interpolation was discarded and a linear interpolation was applied instead.

Spatial interpolation errors affect the calculation of catchment average rainfall from the point measurements and depend on rain gauge density, network design, and rainfall spatial variability, which in turn is affected by topography, rainfall intensity, and storm type ${ }^{44,67}$. Interpolation errors in large catchments can be investigated by subsampling from the rain gauge network ${ }^{67}$. Here, we constrain spatial uncertainty by using at least two rain gauges in catchments much smaller than $20 \mathrm{~km}^{2}$, which is well above the WMO-recommended station density of 1 gauge $250 \mathrm{~km}^{-2}$ for mountain environments ${ }^{47}$. Data gaps identified in the time series are flagged with a letter ' $V$ ' in the raw files, and monitored periods and percentages of data gaps for each sensor are shown in Table 4 (available online only). Rainfall data within each catchment were contrasted between the several rain gauges using double mass plots. We use the 


\begin{tabular}{|c|c|c|c|}
\hline Variable & Uncertainty sources & Investigation method & Reference \\
\hline \multirow[t]{4}{*}{ Precipitation } & Equipment malfunction & Rainfall data with and without quality control & 90 \\
\hline & Point measurement error & Normal distribution with standard deviation as a function of rain rate & 48,51 \\
\hline & $\begin{array}{l}\text { Rainfall intensity interpolation method, rainfall } \\
\text { event definition }\end{array}$ & Composite cubic spline interpolation, threshold intensities, and bias correction & $\begin{array}{l}43,49-51,70 \\
\end{array}$ \\
\hline & Spatial interpolation uncertainty & Subsampling from the available rain gauges in the network & 67 \\
\hline \multirow[t]{5}{*}{ Streamflow } & $\begin{array}{l}\text { Water level measurement uncertainty, barometric } \\
\text { and temperature pressure compensation }\end{array}$ & $\begin{array}{l}\text { Sampling from uniform or normal distributions with standard error of } \pm 5 \mathrm{~mm} \text { or using sensor nominal } \\
\text { accuracy }\end{array}$ & $67,74,75,79,82,91$ \\
\hline & Rating curve uncertainty, calibration and extrapolation & $\begin{array}{l}\text { Constraining uncertainty by using a discharge control structure; voting point likelihood; heteroscedastic } \\
\text { maximum likelihood model }\end{array}$ & $56,81,83,85,92$ \\
\hline & Streamflow time discretisation & Comparing indices calculated at different time steps & 5,92 \\
\hline & Seasonality in hydrological response & Using total length of time series or divided by season & 38,93 \\
\hline & $\begin{array}{l}\text { Hydrological index calculation method, e.g. baseflow } \\
\text { separation method }\end{array}$ & Comparing different algorithms and methods; Correlation analyses; regionalisation & $34,59,64,65,81,87$ \\
\hline
\end{tabular}

Table 5. Considered sources of uncertainty and investigation methods, following Westerberg and McMillan (2015, ref. 67).

double mass plots also to fill data gaps in the rain gauges, but only when the regression coefficient $\left(\mathrm{R}^{2}\right)$ was larger than 0.99. To calculate catchment average rainfall, we used a simple average of rain gauge data within each catchment. Rainfall data between paired catchments were used to fill any remaining gaps, again only when $\mathrm{R}^{2}>0.99$.

\section{Streamflow data uncertainty, quality control, and processing}

Monitoring and processing of streamflow data are affected by several sources of uncertainty (Table 5), from which we consider the most important to be: (i) uncertainty in the measurement of water level and discharge, (ii) rating curve calibration and extrapolation uncertainty (iii) time step used in the calculation of hydrological indices, (iv) seasonality in the hydrological response, and (v) hydrological index calculation method.

Data collected using pressure transducers need temperature and barometric pressure compensation. Daily variations in surface water level have been observed in several studies ${ }^{71-74}$. While this phenomenon has been attributed to a set of confounding factors ${ }^{75}$, including evapotranspiration of riparian vegetation $^{76}$, it may also be the consequence of an inappropriate monitoring design and operation ${ }^{73}$, for instance, external sensors, loggers, or cables directly exposed to solar radiation or precipitation. To minimise these issues, the barometric and submerged sensors of the absolute pressure transducer systems were installed in temperature conditions that were as similar and as buffered as possible. Vented tube sensors, in principle, do not require additional barometric compensation ${ }^{74}$; nonetheless, when using them, we ensure the vented tube was free of obstructions, dry and isolated from direct solar radiation to avoid potential issues as recommended ${ }^{77-79}$. Uncertainty in the measurement of water level time series can be approximated by sampling from a uniform distribution using the nominal sensor accuracy as the estimated error (Table 6). Previous studies have used a uniform distribution with a mid-range value of $\pm 5 \mathrm{~mm}$ (ref. 80 ) to investigate the propagation of uncertainty from discharge data to the calculation of hydrological indices ${ }^{67,81}$. Discharge uncertainty is typically larger than water level uncertainty and can be difficult to estimate especially during high-flow gaugings ${ }^{67}$.

Water level data were validated and corrected using manual observations during each site visit. The water depth over the weir was measured manually with $1 \mathrm{~mm}$ precision and then used to compensate differences with respect to the values collected by the automatic water level sensors. The same convention as for rainfall data was used for water level and discharge data, flagging data in the raw files (i.e., letters 'I', 'D', ' $\mathrm{X}$ ', 'P', and ' $\mathrm{V}$ '). Water level data gaps were only filled for short periods in which the sensors were stopped for data retrieving, which were generally less than a few hours (Table 4 (available online only)). Other data gaps in water level or discharge data were not filled to avoid the manipulation of hydrological data that could result in erroneous attributions of streamflow responses. For instance, a non-linear impact of livestock grazing on the hydrological response time and flow recession curve can be observed in Fig. 4f. A linear interpolation of measurement gaps could affect this non-linear impact and potentially hinder the attribution of observed differences in the hydrological response.

The approximation of the true stage-discharge relation by means of a rating curve is usually a dominant source of uncertainty ${ }^{67,82}$, especially when this relationship changes over time. Processes that affect the validity of the rating curve include changes in roughness, vegetation growth, upstream sediment deposition and erosion, out-of-bank flow ranges, and unsteady flows or backwater effects ${ }^{81,83}$. In the monitored iMHEA catchments, flows are contained within a weir, which constrains the rating curve uncertainty and allows application of a theoretical relation derived from hydraulic principles (the Kindsvater-Shen equation ${ }^{56}$ ). Only in a few catchments was this relation compared to direct flow observations. Table 6 shows the weir dimensions used for the Kindsvater-Shen equation in each 


\begin{tabular}{|c|c|c|c|c|c|}
\hline Station & $90^{\circ} \mathrm{V}$-notch section height $\mathrm{m}$ & Rectangular section width $\mathbf{m}$ & Sensor range $\mathrm{cm} \mathrm{H}_{2} \mathrm{O}$ & Sensor accuracy $\mathrm{cm} \mathrm{H}_{2} \mathrm{O}(\% \mathrm{FS})$ & Sensor resolution $\mathrm{cm} \mathrm{H}_{2} \mathrm{O}$ (\% FS) \\
\hline LLO_01_HI_01 & 0.3030 & 1.2520 & 200 & $\pm 0.12( \pm 0.06)$ & $0.01(0.0034)$ \\
\hline LLO_02_HI_01 & 0.3000 & 1.4000 & 200 & $\pm 0.12( \pm 0.06)$ & $0.01(0.0034)$ \\
\hline JTU_01_HI_01 & 0.2967 & 0.8500 & 200 & $\pm 0.12( \pm 0.06)$ & $0.01(0.0034)$ \\
\hline JTU_02_HI_01 & 0.2961 & 0.7980 & 200 & $\pm 0.12( \pm 0.06)$ & $0.01(0.0034)$ \\
\hline JTU_03_HI_01 & 0.2939 & 0.9000 & 200 & $\pm 0.12( \pm 0.06)$ & $0.01(0.0034)$ \\
\hline JTU_04_HI_01 & 0.0000 & 2.9000 & 200 & $\pm 0.12( \pm 0.06)$ & $0.01(0.0034)$ \\
\hline PIU_01_HI_01 & 0.6000 & 2.3000 & 200 & $\pm 0.12( \pm 0.06)$ & $0.01(0.0034)$ \\
\hline PIU_02_HI_01 & 0.6000 & 2.3000 & 200 & $\pm 0.12( \pm 0.06)$ & $0.01(0.0034)$ \\
\hline PIU_03_HI_01 & 0.3000 & 0.9000 & 200 & $\pm 0.12( \pm 0.06)$ & $0.01(0.0034)$ \\
\hline PIU_04_HI_01 & 0.3000 & 0.9000 & 200 & $\pm 0.12( \pm 0.06)$ & $0.01(0.0034)$ \\
\hline PIU_07_HI_01 & 0.3000 & 0.9000 & 200 & $\pm 0.12( \pm 0.06)$ & $0.01(0.0034)$ \\
\hline CHA_01_HS_01 & 0.2975 & 1.2100 & 1000 & $\pm 0.5( \pm 0.05)$ & Not specified \\
\hline CHA_02_HS_01 & 0.2975 & 1.2000 & 1000 & $\pm 0.5( \pm 0.05)$ & Not specified \\
\hline HUA_01_HD_01 & 1.0000 & 0.0000 & $150-1000$ & $\pm 0.50( \pm 0.05)$ & $0.10-0.20$ \\
\hline HUA_01_HD_02 & 0.3000 & 1.6000 & $150-1000$ & $\pm 0.50( \pm 0.05)$ & $0.10-0.20$ \\
\hline HUA_02_HD_01 & 1.0000 & 0.0000 & $150-1000$ & $\pm 0.50( \pm 0.05)$ & $0.10-0.20$ \\
\hline HUA_02_HD_02 & 0.3000 & 2.2000 & $150-1000$ & $\pm 0.50( \pm 0.05)$ & $0.10-0.20$ \\
\hline HMT_01_HI_01 & 0.2981 & 0.8950 & 200 & $\pm 0.12( \pm 0.06)$ & $0.01(0.0034)$ \\
\hline HMT_02_HI_01 & 0.3000 & 1.5000 & 200 & $\pm 0.12( \pm 0.06)$ & $0.01(0.0034)$ \\
\hline TAM_01_HO_01 & 0.3065 & 1.1520 & $400-900$ & $\pm 0.30-0.50( \pm 0.075)$ & $0.14-0.21$ \\
\hline TAM_02_HO_01 & 0.3095 & 1.1510 & $400-900$ & $\pm 0.30-0.50( \pm 0.075)$ & $0.14-0.21$ \\
\hline TIQ_01_HD_01 & 0.3100 & 2.1100 & 150-1000 & $\pm 0.50-1.00( \pm 0.10)$ & $0.10-0.20$ \\
\hline TIQ_02_HD_01 & 0.3000 & 1.2800 & $150-1000$ & $\pm 0.50-1.00( \pm 0.10)$ & $0.10-0.20$ \\
\hline
\end{tabular}

Table 6. Weir dimensions used to transform water levels to discharge and water level sensor specifications. All V-notch sections used here have a 90-degree angle. FS: full scale.

catchment. Several iMHEA sites have started the task of deriving specific stage-discharge curves to improve the accuracy in the calculation of streamflow data from water levels. In the literature, different parameterisations have been tried, with polynomial functions performing slightly better than power functions ${ }^{83}$. A previous study investigating the use of stage-discharge rating curves in non-ideal conditions for short-term projects, in which measurements were generally gathered by non-specialists, found large uncertainties in the calculation of cumulative annual discharge between -13 and $+14 \%$ (ref. 84 ).

The extremes of the rating curve tend to be more uncertain because of the lower number of low and high flows available as calibration points. Previous studies on quantitative analysis of discharge estimation ${ }^{67,81-83}$ have found that high flow extrapolation is the dominant source of uncertainty as the conditions that control the stage-discharge relationship can be different at water levels much higher than average. These errors can introduce much larger uncertainty than river flow measurements and seasonal changes in roughness. Additionally, being the non-linear least squares method the standard technique to calibrate rating curves, its lack of flexibility may introduce heteroscedasticity that needs to be accounted for $^{85}$. In the case of unsteady flow occurrence, a dynamic rating curve approach can be used to provide an indirect discharge measurement based on simultaneous water level measurements at adjacent cross sections ${ }^{86}$, but this has not been implemented in our monitoring protocol ${ }^{25}$ and is still not common in national level hydrometeorological monitoring elsewhere ${ }^{47}$.

Uncertainty in the calculation of hydrological indices results from the time discretisation of the flow data. This can be investigated by comparing indices calculated at different time steps (e.g. hourly and daily). For instance, using these hydrometeorological data to evaluate the effects of land-use changes, Ochoa-Tocachi et al. (2016, ref. 5) have found that impacts on the short-term hydrological regulation can remain unnoticed on daily aggregated indices but become evident when using high-resolution time series. Other sources of uncertainty arise from seasonal variations in the hydrological response that can provide evidence of catchment intervention impacts ${ }^{38}$ or, in contrast, obscure statistical differences between catchments and between different monitoring periods ${ }^{34}$. The calculation method of particular hydrological indices can also introduce uncertainty in the assessment of catchment interventions. For instance, the baseflow index and its correspondent recession constant were calculated here using two different methods, one proposed by the UK Flood Estimation Handbook ${ }^{64}$ and the other is a twoparameter algorithm ${ }^{65}$ fitted subjectively. The shapes of the derived baseflow time series are similar, and the general trends observed between catchments are consistent. However, the different absolute values can lead to diverse interpretations of how groundwater dominated the catchments are. Lastly, if 
catchment data are pooled, for example in hydrological modelling or regionalisation, then the propagation of uncertainty from rainfall and streamflow data to any derived synthetic time series, model parameter, or hydrological index, as well as the uncertainty in the implemented methods and model structural errors, need to be considered and quantified ${ }^{81,87}$.

\section{Usage Notes}

The iMHEA dataset is intended to analyse the hydrological impacts of human activities in Andean catchments (e.g., land use change), to support the evaluation of hydrological benefits of watershed interventions (e.g., restoration strategies), or to increase understanding of hydrological processes of natural ecosystems and green infrastructure (e.g., water harvesting techniques). Recent applications of these data include evidence-based, robust predictions and cost-benefit comparisons of the effectiveness of different watershed interventions to support institutions in their ex-ante planning, implementation, and ex-post evaluation ${ }^{5,88}$. Such analyses can be extended to hydrological model calibration and regional extrapolation to make predictions in ungauged basins ${ }^{34}$.

We do not consider the data to be suitable for trend analysis because of the short length of the time series. The value of the 'trading-space-for-time approach' relies on the comparison of climate conditions and hydrological responses between the paired catchments, ${ }^{5,38}$. However, users need to be aware that catchments are unique ${ }^{89}$ and their physical characteristics are inherently different, and thus land use and land cover are the main but not the only variance between them. An added value of the monitoring network design is the ability to compare and regionalise results by pooling the catchments together in a regional impact model ${ }^{34}$. In this case, users need to be cautious of the different monitoring periods of sites and catchments which may be influenced by particular regional hydrometeorological drivers.

The iMHEA sites are also available for the implementation of external research projects that can contribute to generate better and more detailed understanding of hydrological processes and impacts of human activities on water quantity and quality, sediment transport, and other ecosystem services. The long-term sustainability in the monitoring of experimental catchments will allow a deeper understanding of seasonality, natural variability, environmental changes, and extreme events such as drought and flooding ${ }^{26}$. The sites have been defined based on their socioeconomic relevance for local and regional stakeholders and can benefit from extending the monitoring to other variables or methods of interest. We invite researchers worldwide to make use of this dataset, and to engage in and complement the monitoring of these and new iMHEA sites.

The data are freely available under the Creative Commons Licence: CC BY 4.0.

\section{References}

1. Körner, C. et al. in Millennium Ecosystem Assessment. Ecosystems and Human Well-being: Current State and Trends (eds Hassan R., Scholes R., Ash N.) 24, 681-716 (Island Press: Washington DC, United States, 2005).

2. Viviroli, D., Dürr, H. H., Messerli, B., Meybeck, M. \& Weingartner, R. Mountains of the world, water towers for humanity: Typology, mapping, and global significance. Water Resour. Res. 43, 1-13 (2007).

3. Buytaert, W. et al. Human impact on the hydrology of the Andean páramos. Earth-Sci. Rev. 79, 53-72 (2006).

4. Bradshaw, C. J. A., Sodhi, N. S., Peh, K. S.-H. S. \& Brook, B. W. Global evidence that deforestation amplifies flood risk and severity in the developing world. Glob. Change Biol. 13, 2379-2395 (2007).

5. Ochoa-Tocachi, B. et al. Impacts of land use on the hydrological response of tropical Andean catchments. Hydrol. Process. 30, 4074-4089 (2016).

6. Bradley, R. S., Vuille, M., Diaz, H. F. \& Vergara, W. Climate change. Threats to water supplies in the tropical Andes. Science 312, 1755-1756 (2006).

7. Urrutia, R. \& Vuille, M. Climate change projections for the tropical Andes using a regional climate model: Temperature and precipitation simulations for the end of the 21st century. J. Geophys. Res. Atmos 114, 1-15 (2009).

8. Zulkafli, Z. et al. Projected increases in the annual flood pulse of the Western Amazon. Environ. Res. Lett. 11, 014013 (2016).

9. Wohl, E. et al. The hydrology of the humid tropics. Nat. Clim. Change 2, 655-662 (2012).

10. Fekete, B. M. \& Vörösmarty, C. J. The current status of global river discharge monitoring and potential new technologies complementing traditional discharge measurements. Predictions in Ungauged Basins: PUB Kick-off. IAHS-AISH Publication 309, 129-136 (2007).

11. Célleri, R., Buytaert, W., De Bièvre, B. \& Tobón, C. Understanding the hydrology of tropical Andean ecosystems through an Andean Network of Basins. Status and Perspectives of Hydrology in Small Basins. IAHS-AISH Publication 336, 209-212 (2010).

12. Viviroli, D. et al. Climate change and mountain water resources: overview and recommendations for research, management and policy. Hydrol. Earth Syst. Sci. 15, 471-504 (2011).

13. Buytaert, W. \& De Bièvre, B. Water for cities: The impact of climate change and demographic growth in the tropical Andes. Water Resour. Res. 48, W08503 (2012).

14. Roa García, C. E. \& Brown, S. Assessing water use and quality through youth participatory research in a rural Andean watershed. J. Environ. Manage. 90, 3040-3047 (2009).

15. Buytaert, W., Baez, S., Bustamante, M. \& Dewulf, A. Web-based environmental simulation: Bridging the gap between scientific modeling and decision-making. Environ. Sci. Technol. 46, 1971-1976 (2012).

16. Buytaert, W. et al. Citizen science in hydrology and water resources: opportunities for knowledge generation, ecosystem service management, and sustainable development. Front. Earth Sci 2, 1-21 (2014).

17. Buytaert, W., Dewulf, A., De Bièvre, B., Clark, J. \& Hannah, D. M. Citizen Science for Water Resources Management: Toward Polycentric Monitoring and Governance? J. Water Resour. Plan. Manag 142, 01816002 (2016).

18. Paul, J. D. et al. Citizen science for hydrological risk reduction and resilience building. WIREs Water 5, e1262 (2018).

19. Kummerow, C., Barnes, W., Kozu, T., Shiue, J. \& Simpson, J. The Tropical Rainfall Measuring Mission (TRMM) sensor package. J. Atmospheric Ocean. Technol 15, 809-817 (1998).

20. Hou, A. Y. et al. The global precipitation measurement mission. Bull. Am. Meteorol. Soc 95, 701-722 (2014).

21. Tapley, B. D., Bettadpur, S., Ries, J. C., Thompson, P. F. \& Watkins, M. M. GRACE Measurements of Mass Variability in the Earth System. Science 503, 21-24 (2011). 
22. Entekhabi, D. et al. The soil moisture active passive (SMAP) mission. Proc. IEEE 98, 704-716 (2010).

23. Manz, B. et al. High-resolution satellite-gauge merged precipitation climatologies of the Tropical Andes. J. Geophys. Res. Atmos 121, 1190-1207 (2016)

24. Manz, B. et al. Comparative Ground Validation of IMERG and TMPA at Variable Spatio-temporal Scales in the Tropical Andes. J. Hydrometeorol 18, 2469-2489 (2017).

25. Ochoa-Tocachi, B. F., Buytaert, W., De Bièvre, B. in Andean Hydrology (eds Rivera D. A., Godoy-Faundez A. \& Lillo Saavedra M.) Chapter 6, 126-163 (CRC Press Taylor and Francis Group, Portland, USA, 2017).

26. Tetzlaff, D., Carey, S. K., McNamara, J. P., Laudon, H. \& Soulsby, C. The essential value of long-term experimental data for hydrology and water management. Water Resour. Res. 53, 2598-2604 (2017).

27. Bogena, H. et al. TERENO: German network of terrestrial environmental observatories. J. Large-scale Res. Fac 2, A52 (2016).

28. Buytaert, W. \& Beven, K. Regionalization as a learning process. Water Resour. Res. 45, W11419 (2009).

29. Buytaert, W. \& Beven, K. Models as multiple working hypotheses: hydrological simulation of tropical alpine wetlands. Hydrol. Process. 25, 1784-1799 (2011).

30. Oudin, L., Kay, A., Andréassian, V. \& Perrin, C. Are seemingly physically similar catchments truly hydrologically similar? Water Resour. Res. 46, W11558 (2010).

31. Singh, R., Wagener, T., van Werkhoven, K., Mann, M. E. \& Crane, R. A trading-space-for-time approach to probabilistic continuous streamflow predictions in a changing climate-accounting for changing watershed behavior. Hydrol. Earth Syst. Sci. 15, 3591-3603 (2011).

32. Sivapalan, M., Yaeger, M. A., Harman, C. J., Xu, X. \& Troch, P. A. Functional model of water balance variability at the catchment scale: 1. Evidence of hydrologic similarity and space-time symmetry. Water Resour. Res. 47, W02522 (2011).

33. Wagener, T. \& Montanari, A. Convergence of approaches toward reducing uncertainty in predictions in ungauged basins. Water Resour. Res. 47, W06301 (2011).

34. Ochoa-Tocachi, B. F., Buytaert, W. \& De Bièvre, B. Regionalization of land-use impacts on streamflow using a network of paired catchments. Water Resour. Res. 52, 6710-6729 (2016).

35. Bosch, J. M. \& Hewlett, J. D. A review of catchment experiments to determine the effect of vegetation changes on water yield and evapotranspiration. J. Hydrol. 55, 3-23 (1982).

36. Lørup, J. K., Refsgaard, J. C. \& Mazvimavi, D. Assessing the effect of land use change on catchment runoff by combined use of statistical tests and hydrological modelling: Case studies from Zimbabwe. J. Hydrol. 205, 147-163 (1998).

37. Bulygina, N., McIntyre, N. \& Wheater, H. Conditioning rainfall-runoff model parameters for ungauged catchments and land management impacts analysis. Hydrol. Earth Syst. Sci. 13, 893-904 (2009).

38. Brown, A. E., Zhang, L., McMahon, T. A., Western, A. W. \& Vertessy, R. A A review of paired catchment studies for determining changes in water yield resulting from alterations in vegetation. J. Hydrol. 310, 28-61 (2005).

39. Buytaert, W., Iñiguez, V. \& De Bièvre, B. The effects of afforestation and cultivation on water yield in the Andean páramo. For. Ecol. Manag 251, 22-30 (2007).

40. McIntyre, N. et al. Modelling the hydrological impacts of rural land use change. Hydrol. Res. 45, 737-754 (2014).

41. Favier, V. et al. Evidence of groundwater flow on Antizana ice-covered volcano, Ecuador. Hydrol. Sci. J 53, 278-291 (2008).

42. Mosquera, G. M., Lazo, P. X., Célleri, R., Wilcox, B. P. \& Crespo, P. Runoff from tropical alpine grasslands increases with areal extent of wetlands. Catena 125, 120-128 (2015).

43. Padrón, R. S., Wilcox, B. P., Crespo, P. \& Célleri, R. Rainfall in the Andean Páramo: New Insights from High-Resolution Monitoring in Southern Ecuador. J. Hydrometeorol. 16, 985-996 (2015).

44. Buytaert, W., Celleri, R., Willems, P., Bièvre, B. D. \& Wyseure, G. Spatial and temporal rainfall variability in mountainous areas: A case study from the south Ecuadorian Andes. J. Hydrol. 329, 413-421 (2006).

45. Célleri, R., Willems, P., Buytaert, W. \& Feyen, J. Space-time rainfall variability in the Paute Basin, Ecuadorian Andes. Hydrol. Process. 21, 3316-3327 (2007).

46. World Meteorological Organization. Guide to Meteorological Instruments and Methods of observation. WMO-No. 8. (World Meteorological Organization: Geneva, Switzerland, 2014).

47. World Meteorological Organization. Guide to Hydrological Practices, Volume I, Hydrology - From Measurement to Hydrological Information. WMO-No. 168. (World Meteorological Organization: Geneva, Switzerland, 2008).

48. Muñoz, P., Célleri, R. \& Feyen, J. Effect of the resolution of tipping-bucket rain gauge and calculation method on rainfall intensities in an Andean mountain gradient. Water 8, 534w8110534 (2016).

49. Sadler, E. J. \& Busscher, W. J. High-intensity rainfall rate determination from tipping-bucket rain gauge data. Agron. J 81, 930-934 (1989).

50. Wang, J., Fisher, B. L. \& Wolff, D. B. Estimating rain rates from tipping-bucket rain gauge measurements. J. Atmospheric Ocean. Technol 25, 43-56 (2008)

51. Ciach, G. J. \& City, I. Local Random Errors in Tipping-Bucket Rain Gauge Measurements. J. Atmospheric Ocean. Technol 20, 752-759 (2003)

52. Walsh, R. P. \& Lawler, D. M. Rainfall Seasonality: Description, Spatial Patterns and Change through Time. Weather 36, 201-208 (1981)

53. Hijmans, R. J., Cameron, S. E., Parra, J. L., Jones, P. G. \& Jarvis, A. Very high resolution interpolated climate surfaces for global land areas. Int. J. Climatol. 25, 1965-1978 (2005).

54. Hargreaves, G. H. \& Samani, Z. A. Reference Crop Evapotranspiration from Temperature. Appl. Eng. Agric. 1, 96-99 (1985).

55. Allen, R. G., Pereira, L. S., Raes, D. \& Smith, M. Crop evapotranspiration - Guidelines for computing crop water requirements. FAO-No 56. (Food and Agriculture Organization of the United Nations: Rome, Italy, 1998).

56. U. S. Department of the Interior Bureau of Reclamation. Water measurement manual. Tech. Rep. (United States Department of Agriculture (USDA): Washington, D.C., United States, 2001).

57. Poff, N. L. \& Ward, J. V. Implications of streamflow variability and predictability for lotic community structure: A regional analysis of streamflow patterns. Can. J. Fish. Aquat. Sci. 46, 1805-1818 (1989).

58. Richter, B. D., Baumgartner, J. V., Powell, J. \& Braun, D. P. A Method for Assessing Hydrologic Alteration within Ecosystems. Conserv. Biol. 10, 1163-1174 (1996).

59. Olden, J. D. \& Poff, N. L. Redundancy and the choice of hydrologic indices for characterizing streamflow regimes. River Res. Appl. 19, 101-121 (2003)

60. Sefton, C. E. \& Howarth, S. M. Relationships between dynamic response characteristics and physical descriptors of catchments in England and Wales. J. Hydrol. 211, 1-16 (1998).

61. Almeida, S., Le Vine, N., McIntyre, N., Wagener, T. \& Buytaert, W. Accounting for dependencies in regionalized signatures for predictions in ungauged catchments. Hydrol. Earth Syst. Sci. 20, 887-901 (2016).

62. Archer, D. R., Climent-Soler, D. \& Holman, I. P. Changes in discharge rise and fall rates applied to impact assessment of catchment land use. Hydrol. Res. 41, 13-26 (2010).

63. Baker, D. B., Richards, R. P., Loftus, T. T. \& Kramer, J. W. A new flashiness index: Characteristics and applications to midwestern rivers and streams. Journal of the American Water Resources Association 40, 503-522 (2004). 
64. Gustard, A., Bullock, A. \& Dixon, J. M. Low flow estimation in the United Kingdom. Report No. 108. (Institute of Hydrology: Wallingford, United Kingdom, 1992).

65. Chapman, T. A comparison of algorithms for stream flow recession and base flow separation. Hydrol. Process. 13, 701-714 (1999).

66. Ochoa-Tocachi, B. F. Data processing code for: Regional Initiative for Hydrological Monitoring of Andean Ecosystems iMHEA. GitHub, available at https://github.com/topicster/iMHEA_scriptslast (accessed 16.02.2018).

67. Westerberg, I. K. \& McMillan, H. K. Uncertainty in hydrological signatures. Hydrol. Earth Syst. Sci. 19, 3951-3968 (2015).

68. Sieck, L. C., Burges, S. J. \& Steiner, M. Challenges in obtaining reliable measurements of point rainfall. Water Resour. Res. 43, W01420 (2007).

69. Onset Computer Corporation. Data Logging Rain Gauge RG3 and RG3-M User's Manual (Onset Computer Corporation, 2011).

70. Habib, E., Krajewski, W. F. \& Kruger, A. Sampling errors of tipping-bucket rain gauge measurements. J. Hydrol. Eng. 6, 159-166 (2001).

71. Bond, B. J. et al. The zone of vegetation influence on baseflow revealed by diel patterns of streamflow and vegetation water use in a headwater basin. Hydrol. Process. 16, 1671-1677 (2002).

72. Wondzell, S. M., Gooseff, M. N. \& McGlynn, B. L. An analysis of alternative conceptual models relating hyporheic exchange flow to diel fluctuations in discharge during baseflow recession. Hydrol. Process. 24, 686-694 (2009).

73. McLaughlin, D. L. \& Cohen, M J. Thermal artifacts in measurments of fine-scale water level variation. Water Resour. Res. 47, W09601 (2011)

74. Gribovszki, Z., Kalicz, P. \& Szilágyi, J. Does the accuracy of fine-scale water level measurements by vented pressure transducers permit for diurnal evapotranspiration estimation? J. Hydrol. 488, 166-169 (2013).

75. Cuevas, J. G., Calvo, M., Little, C., Pino, M. \& Dassori, P. Are diurnal fluctuations in streamflow real? J. Hydrol. Hydromech. 58, 149-162 (2010)

76. White, W. N. A method of estimating ground-water supplies based on discharge by plants and evaporation from soil - results of investigation in Escalante Valley, UtahWater Supply Paper 659, 105, (U.S. Geological Survey, 1932).

77. Freeman, L. A. et al. Use of Submersible Pressure Transducers in Water-Resources Investigations, 52 (U.S. Geological Survey, 2004).

78. Cain, S. F., Gregory, D. A., Loheide, S. P. \& Butler, J. J. Noise in pressure trassducers readings produced by variations in solar radiation. Ground Water 42, 939-944 (2004).

79. Gribovszki, Z., Szilágyi, J. \& Kalicz, P. Diurnal fluctuations in shallow groundwater levels and streamflow rates and their interpretation - A review. J. Hydrol. 385, 371-383 (2010).

80. McMillan, H., Krueger, T. \& Freer, J. Benchmarking observational uncertainties for hydrology: rainfall, river discharge and water quality. Hydrol. Process. 26, 4078-4111 (2012).

81. Westerberg, I. K. et al. Uncertainty in hydrological signatures for gauged and ungauged catchments. Water Resour. Res. 52, 1847-1865 (2016).

82. Coxon, G. et al. A novel framework for discharge uncertainty quantification applied to 500 UK gauging stations. Water Resour. Res. 51, 5531-5546 (2015).

83. Di Baldassarre, G. \& Montanari, A. Uncertainty in river discharge observations: a quantitative analysis. Hydrol. Earth Syst. Sci. 13, 913-921 (2009)

84. Birgand, F., Lellouche, G. \& Appelboom, T. W. Measuring flow in non-ideal conditions for short-term projects: Uncertainties associated with the use of stage-discharge rating curves. J. Hydrol. 503, 186-195 (2013).

85. Petersen-Øverleir, A. Accounting for heteroscedasticity in rating curve estimates. J. Hydrol. 292, 173-181 (2004).

86. Dottori, F., Martina, M. L. V. \& Todini, E. A dynamic rating curve approach to indirect discharge measurement. Hydrol. Earth Syst. Sci. 13, 847-863 (2009).

87. Yadav, M., Wagener, T. \& Gupta, H. Regionalization of constraints on expected watershed response behavior for improved predictions in ungauged basins. Adv. Water Resour. 30, 1756-1774 (2007).

88. Gammie, G. \& De Bièvre, B. Assessing Green Interventions for the Water Supply of Lima, Peru. Cost-Effectiveness, Potential Impact, and Priority Research Areas. Tech. rep (Forest Trends: Washington, D.C., United States, 2015).

89. Beven, K. J. Uniqueness of place and process representations in hydrological modelling. Hydrol. Earth Syst. Sci. 4, 203-213 (2000).

90. Wood, S. J., Jones, D. A. \& Moore, R. J. Accuracy of rainfall measurement for scales of hydrological interest. Hydrol. Earth Syst. Sci. 4, 531-543 (2000).

91. Guallpa, M. \& Célleri, R. Effect of atmospheric pressure estimation on stage and discharge calculations. Aqua-LAC 5, 56-68 (2013)

92. McMillan, H. K. \& Westerberg, I. K. Rating curve estimation under epistemic uncertainty. Hydrol. Process. 29, 1873-1882 (2015).

93. Shaw, S. B. \& Riha, S. J. Examining individual recession events instead of a data cloud: using a modified interpretation of dQ/dt-Q streamflow recession in glaciated watersheds to better inform models of low flow. J. Hydrol. 434, 46-54 (2012).

\section{Data Citation}

1. Ochoa-Tocachi, B. F. et al. Figshare https://doi.org/10.6084/m9.figshare.c.3943774 (2018)

\section{Acknowledgements}

The authors gratefully acknowledge the people and authorities of Andean communities who have provided important and constant consent and support to our fieldwork. We thank all partners of the Regional Initiative for Hydrological Monitoring of Andean Ecosystems (iMHEA), particularly to FONAG, Universidad de Cuenca, NCI, APECO, The Mountain Institute, CONDESAN, and LHUMSS who provided the data presented here. In addition, we would like to acknowledge the important contributions of Alexander More (NCI), Katya Pérez and María Arguello and Miguel Saravia (CONDESAN), Mariela Leo (APECO), Jorge Recharte (The Mountain Institute), and Gena Gammie (Forest Trends) as key stakeholders of iMHEA. This work was supported by grant NE/K010239-1 (Mountain-EVO) funded by the UK Department for International Development (DFID), the Economic and Social Research Council (ESRC), and the Natural Environment Research Council (NERC), as well as NERC grant NE/I004017/1. B.O.T. was funded by an Imperial College President's PhD Scholarship and the 'Science and Solutions for a Changing Planet' DTP (NERC grant NE/L002515/1). All iMHEA partners funded fieldwork.

\section{Author Contributions}

B.O.T. wrote the article. B.D.B., W.B., L.A., R.C., P.C., C.L., P.V. conceptualised the monitoring network. B.O.T., W.B., B.D.B., L.A., R.C., P.C., M.V.1. designed the monitoring protocol. B.O.T., J.A., J.D.B., P.F., J. 
G.R., M.G., D.O., P.P., G.R., M.V.2., P.V. set up the experimental catchments, and collected and curated the hydrometeorological data. B.O.T. wrote the data processing scripts and processed the data. J.A. compiled and processed the geographic data. B.O.T. had full access to all the data in the study and takes responsibility for the integrity of the data and the accuracy of the data analysis. All authors contributed to the article development, read, and approved the final version of the manuscript. From the $4^{\text {th }}$ author, the names are listed alphabetically and not according to the individual contributions. The last author (B.D.B.) is the Regional Coordinator (chair) of iMHEA.

\section{Additional Information}

Table 4 is available only in the online version of this paper.

Competing interests: The authors declare no competing interests.

How to cite this article: Ochoa-Tocachi B. F. et al. High-resolution hydrometeorological data from a network of headwater catchments in the tropical Andes. Sci. Data 5:180080 doi: 10.1038/sdata.2018.80 (2018).

Publisher's note: Springer Nature remains neutral with regard to jurisdictional claims in published maps and institutional affiliations.

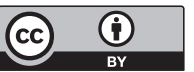

Open Access This article is licensed under a Creative Commons Attribution 4.0 International License, which permits use, sharing, adaptation, distribution and reproduction in any medium or format, as long as you give appropriate credit to the original author(s) and the source, provide a link to the Creative Commons license, and indicate if changes were made. The images or other third party material in this article are included in the article's Creative Commons license, unless indicated otherwise in a credit line to the material. If material is not included in the article's Creative Commons license and your intended use is not permitted by statutory regulation or exceeds the permitted use, you will need to obtain permission directly from the copyright holder. To view a copy of this license, visit http://creativecommons. org/licenses/by/4.0/

The Creative Commons Public Domain Dedication waiver http://creativecommons.org/publicdomain/ zero/1.0/ applies to the metadata files made available in this article.

(c) The Author(s) 2018

Boris F. Ochoa-Tocachi ${ }^{1,2}$, Wouter Buytaert ${ }^{1,2}$, Javier Antiporta ${ }^{2,3}$, Luis Acosta ${ }^{2,4}$, Juan D. Bardales 2,4, Rolando Célleri', , Patricio Crespo ${ }^{2,5}$, Paola Fuentes ${ }^{2,6}$, Junior Gil-Ríos ${ }^{2,4}$, Mario Guallpa ${ }^{2,7}$, Carlos Llerena ${ }^{2,8}$, Dimas Olaya ${ }^{2,4,9}$, Pablo Pardo ${ }^{2,10}$, Gerver Rojas ${ }^{2,11}$, Marcos Villacís ${ }^{2,12}$, Mauricio Villazón ${ }^{2,10}$, Paúl Viñas ${ }^{2,9}$ \& Bert De Bièvre ${ }^{2,6}$

\footnotetext{
${ }^{1}$ Imperial College London, Department of Civil and Environmental Engineering \& Grantham Institute - Climate Change and the Environment, London SW7 2AZ, UK. ${ }^{2}$ Regional Initiative for Hydrological Monitoring of Andean Ecosystems (iMHEA), Lima 15024, Peru. ${ }^{3}$ Consorcio para el Desarrollo Sostenible de la Ecorregión Andina (CONDESAN), Área de Cuencas Andinas, Lima 15024, Peru. ${ }^{4}$ Superintendencia Nacional de Servicios de Saneamiento (SUNASS), Gerencia de Regulación Tarifaria, Lima 15073, Peru. ${ }^{5}$ Universidad de Cuenca, Departamento de Recursos Hídricos y Ciencias Ambientales (iDRHiCA), Facultad de Ciencias Agropecuarias, Facultad de Ingeniería, Cuenca 010203, Ecuador. ${ }^{6}$ Fideicomiso Mercantil Fondo Ambiental para la Protección de Cuencas y Agua (FONAG), Secretaría Técnica \& Programa de Recuperación de la Cobertura Vegetal, Quito 170137, Ecuador. ${ }^{7}$ Empresa Pública Municipal de Telecomunicaciones, Agua Potable, Alcantarillado y Saneamiento de Cuenca (ETAPA EP), Subgerencia de Gestión Ambiental, Cuenca 010101, Ecuador. ${ }^{8}$ Universidad Nacional Agraria La Molina (UNALM), Facultad de Ciencias Forestales, Lima 12056, Peru. ${ }^{9}$ Naturaleza y Cultura Internacional (NCI), Piura 20009, Peru. ${ }^{10}$ Universidad Mayor de San Simón, Laboratorio de Hidráulica (LHUMSS) \& Facultad de Ciencias y Tecnología, Cochabamba 6760, Bolivia. ${ }^{11}$ Asociación Peruana para la Conservación de la Naturaleza (APECO), Chachapoyas 01001, Peru. ${ }^{12}$ Escuela Politécnica Nacional (EPN), Departamento de Ingeniería Civil y Ambiental, Quito 170525, Ecuador.
} 